Жемела Г. П., доктор сільськогосподарських наук, професор, Шевніков Д. М., аспірант *

Полтавська державна аграрна академія

\title{
ВПЛИВ АГРОЕКОЛОГІЧНИХ ФАКТОРІВ НА РІСТ ПШЕНИЦІ ТВЕРДОЇ ЯРОЇ ЗАЛЕЖНО ВІД МІНЕРАЛЬНИХ ДОБРИВ ТА БІОПРЕПАРАТІВ
}

\author{
Рецензент - доктор сільськогосподарських наук, професор С. М. Каленська
}

\begin{abstract}
Застосування мінеральних добрив та інокуляиії насіння пиениці твердої ярої біопрепаратами позитивно вплинуло на ріст і розвиток рослин. Дія мінеральних добрив на висоту рослин виявилася більи суттєвою, ніж дія біопрепаратів, але їхній комплексний вплив був більи ефективним щзодо збільшення ростових прочесів у рослин пшениці твердої ярої; у ичьому разі не проявилася негативна дія несприятливих факторів вететаційного періоду. Без застосування доб-

рив висота рослин була 63,6 cм, із застосуванням поліміксобактерину збільшувалася до 67,2, діазофіту - до 68,6 сантиметрів.
\end{abstract}

Ключові слова: пшениия тверда яра, мінеральні добрива, поліміксобактерин, діазофіт, висота рослин.

Постановка проблеми. У природних умовах ріст і розвиток рослин залежить від комплексу зовнішніх факторів, зокрема, грунту, поживних речовин, світла, вологи, тепла тощо. Сприятливе поєднання вказаних факторів посилює ростові процеси, а за їхньої нестачі або надлишку спостерігається послаблення розвитку рослин. Незважаючи на те, що вивченню й розробці агротехніки вирощування пшениці здавна надавалася значна увага, проте експериментальних даних щодо ростових процесів рослин пшениці ярої у весняно-літній період вегетації залежно від рівня мінерального живлення та біопрепаратів та в зв'язку з суттєвими змінами клімату в умовах лівобережної частини Лісостепу України зустрічається обмаль.

Аналіз основних досліджень і публікацій, у яких започатковано розв'язання проблеми. Найсприятливіші умови для досягнення високої продуктивності рослин, а також для підтримання родючості грунту на потрібному рівні, створюються за повного забезпечення їх елементами живлення [1]. Доступними ж поживними елементами рослини забезпечуються в результаті мінералізації органічних сполук грунтовими мікроорганізмами і переходу мінеральних важкорозчинних речовин у розчинні $[2,3]$.
Висока продуктивність і якість зерна досягаються за оптимального співвідношення вказаних вище факторів на всіх етапах росту й розвитку рослин. Враховуючи способи, які позитивно або негативно впливають на врожайність, можна суттєво зменшити негативну дію метеорологічних умов $\mathrm{i}$ цілеспрямовано використовувати елементи технології вирощування, що їх може контролювати людина $[4,5]$. У зв'язку з цим неабияке значення має застосування агротехнічних заходів, спрямованих на максимальну економію використання грунтової вологи в процесі формування врожайності. Важливою умовою зменшення коефіцієнта водоспоживання рослин $\epsilon$ створення оптимального режиму мінерального живлення, що забезпечує найкращий розвиток рослин по етапах органогенезу й отримання високої врожайності [6].

Застосування біологічних і хімічних засобів у технологіях вирощування пшениці позитивно впливає на ріст і розвиток окремих органів та рослинного організму в цілому. Тому необхідною умовою їхнього використання є комплексне вивчення впливу на формування врожайності та якості зерна [7].

Мета і завдання дослідження. Метою наших досліджень було вивчити особливості росту i розвитку рослин пшениці твердої ярої залежно від умов вирощування; встановити норми внесення мінеральних добрив за умови застосування біопрепаратів, що сприяють оптимальному розвитку надземної і підземної частини рослин $\mathrm{i}$ забезпечують формування стабільно великої врожайності зерна незалежно від погодних умов.

Завдання досліджень - вивчити особливості росту, розвитку рослин за використання передпосівної обробки насіння різними біологічними препаратами залежно від рівня мінерального живлення та встановити їхнє оптимальне співвідношення для забезпечення формування стабільної врожайності зерна пшениці твердої ярої 3 високими якісними характеристиками.

\footnotetext{
* Науковий керівник - доктор сільськогосподарських наук, професор Г. П. Жемела
} 
Матеріали і методи досліджень. Основні дослідження проводили на дослідному полі Полтавського інституту АПВ ім. М. І. Вавилова в 2010-2012 рр. Вивчали вплив передпосівної обробки насіння мікробіологічними препаратами залежно від розрахованого балансовим методом фону мінерального живлення рослин на врожайність 3 т/га зерна. Вивчали шість фонів мінерального живлення: без добрив - контроль; $\mathrm{N}_{45}$; $\mathrm{P}_{45} \mathrm{~K}_{30} ; \mathrm{N}_{45} \mathrm{P}_{45} \mathrm{~K}_{30} ; \mathrm{N}_{23} \mathrm{P}_{23} \mathrm{~K}_{15}$; солома попередника $+\mathrm{N}_{10}$ на кожну тонну побічної продукції. Протягом вегетаційного періоду проводили спостереження за ростом і розвитком рослин.

Результати досліджень. Застосування мінеральних добрив та інокуляція насіння пшениці ярої біопрепаратами позитивно вплинули на ріст і розвиток рослин (див. табл.). У фазі колосіння висота рослин пшениці без застосування добрив та інокуляції в 2010 році становила 56,7 см, за використання поліміксобактерину вона збільшилася до 65,8 см, діазофіту - до 68,9 см, за сумісного їхнього застосування - до 63,9 сантиметрів. За використання мінеральних добрив у дозі $\mathrm{N}_{45} \mathrm{P}_{45} \mathrm{~K}_{30}$ висота рослин збільшилась до $62,5 \mathrm{~cm}$ без інокуляції. За сумісної дії добрив та біопрепаратів цей показник був у межах 71,7-73,6 см. За зменшення дози добрив вдвічі $\left(\mathrm{N}_{23} \mathrm{P}_{23} \mathrm{~K}_{15}\right)$ висота рослин без інокуляції становила $62,0 \mathrm{~cm}$, за обробки насіння мікробіопрепаратами - 66,670,5 сантиметрів. Результати кореляційного аналізу свідчать, що біопрепарати збільшували висоту рослин: на 15,9 \% (поліміксобактерин), 17,0 \% (діазофіт) і 13,2\% (сумісне застосування двох препаратів). Що стосується мінеральних добрив, то збільшення висоти рослин пшениці максимальним було за внесення $\mathrm{N}_{45} \mathrm{P}_{45} \mathrm{~K}_{30}$ (на 9,9\%).

\section{Висота рослин пиениці твердої ярої залежно від дії мінеральних добрив ma бionpenаратів, см}

\begin{tabular}{|c|c|c|c|c|}
\hline \multirow[b]{2}{*}{$\begin{array}{c}\text { Варіанти } \\
\text { удобрення }\end{array}$} & \multicolumn{4}{|c|}{ Інокуляція зерна біопрепаратами } \\
\hline & без інокуляції & $\begin{array}{c}\text { поліміксо- } \\
\text { бактерин }\end{array}$ & діазофіт & $\begin{array}{c}\text { суміш поліміксо- } \\
\text { бактерину } \\
\text { та діазофіту }\end{array}$ \\
\hline \multicolumn{5}{|c|}{2010 рік } \\
\hline Без добрив & 56,7 & 65,8 & 68,9 & 63,9 \\
\hline $\mathrm{N}_{45} \mathrm{P}_{45} \mathrm{~K}_{30}$ & 62,5 & 73,6 & 72,7 & 71,7 \\
\hline $\begin{array}{c}\text { Солома попередни- } \\
\text { ка }+\mathrm{N}_{10} \text { на тонну } \\
\text { побічної продукції }\end{array}$ & 63,0 & 70,8 & 67,8 & 67,3 \\
\hline $\mathrm{N}_{23} \mathrm{P}_{23} \mathrm{~K}_{15}$ & 62,0 & 66,6 & 70,5 & 68,3 \\
\hline $\mathrm{N}_{45}$ & 58,5 & 71,9 & 72,9 & 70,5 \\
\hline $\mathrm{P}_{45} \mathrm{~K}_{30}$ & 57,6 & 68,8 & 68,8 & 66,0 \\
\hline \multicolumn{5}{|c|}{2011 рік } \\
\hline Без добрив & 84,0 & 85,5 & 86,7 & 86,4 \\
\hline $\mathrm{N}_{45} \mathrm{P}_{45} \mathrm{~K}_{30}$ & 90,2 & 90,0 & 97,5 & 98,2 \\
\hline $\begin{array}{c}\text { Солома попередни- } \\
\text { ка }+\mathrm{N}_{10} \text { на тонну } \\
\text { побічної продукції }\end{array}$ & 86,2 & 86,3 & 86,5 & 87,2 \\
\hline $\mathrm{N}_{23} \mathrm{P}_{23} \mathrm{~K}_{15}$ & 89,2 & 90,6 & 95,9 & 99,6 \\
\hline N45 & 85,3 & 86,4 & 88,9 & 89,0 \\
\hline $\mathrm{P}_{45} \mathrm{~K}_{30}$ & 84,3 & 86,1 & 87,4 & 87,1 \\
\hline \multicolumn{5}{|c|}{2012 рік } \\
\hline Без добрив & 50,0 & 50,4 & 50,2 & 50,1 \\
\hline $\mathrm{N}_{45} \mathrm{P}_{45} \mathrm{~K}_{30}$ & 55,9 & 56,6 & 63,0 & 63,2 \\
\hline $\begin{array}{c}\text { Солома попередни- } \\
\text { ка }+\mathrm{N}_{10} \text { на тонну } \\
\text { побічної продукції }\end{array}$ & 55,4 & 55,8 & 60,1 & 61,5 \\
\hline $\mathrm{N}_{23} \mathrm{P}_{23} \mathrm{~K}_{15}$ & 55,9 & 56,9 & 60,1 & 61,5 \\
\hline $\mathrm{N}_{45}$ & 55,4 & 56,9 & 61,1 & 61,5 \\
\hline $\mathrm{P}_{45} \mathrm{~K}_{30}$ & 54,4 & 55,5 & 55,7 & 59,3 \\
\hline
\end{tabular}


口Без інокуляції $\square$ Поліміксобактерин $\quad$ УДіазофіт $\quad \square$ Суміш поліміксобактерину та діазофріту

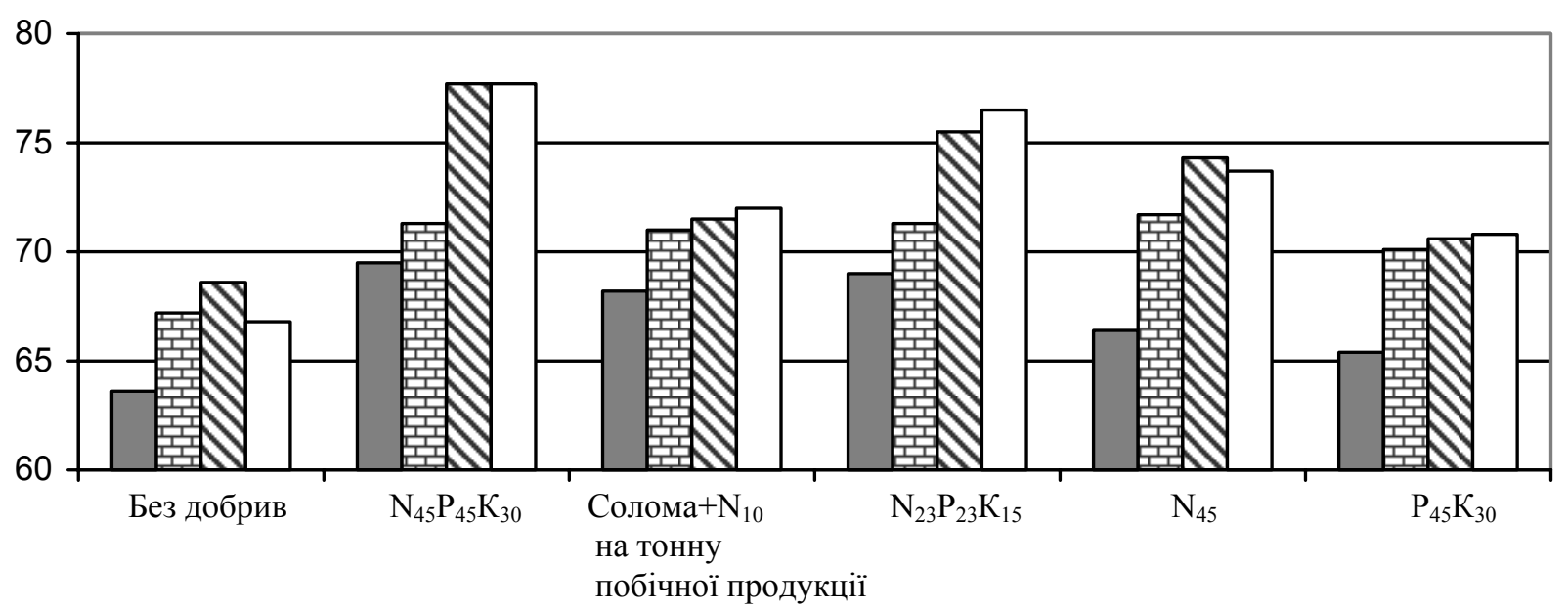

Рис. 1. Висота рослин пшениці твердої ярої залежно від дї мінеральних добрив та біопрепаратів (середнс за 2010-2012 рр.)

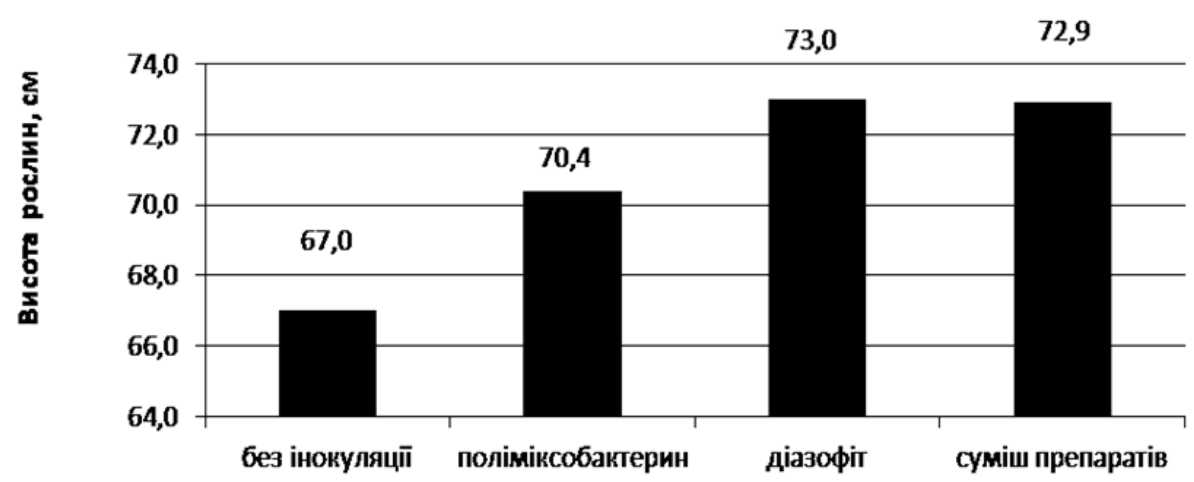

Рис. 2. Висота рослин пиениці твердої ярої залежно від впливу інокуляції зерна біопрепаратами (2010-2012 pp.)

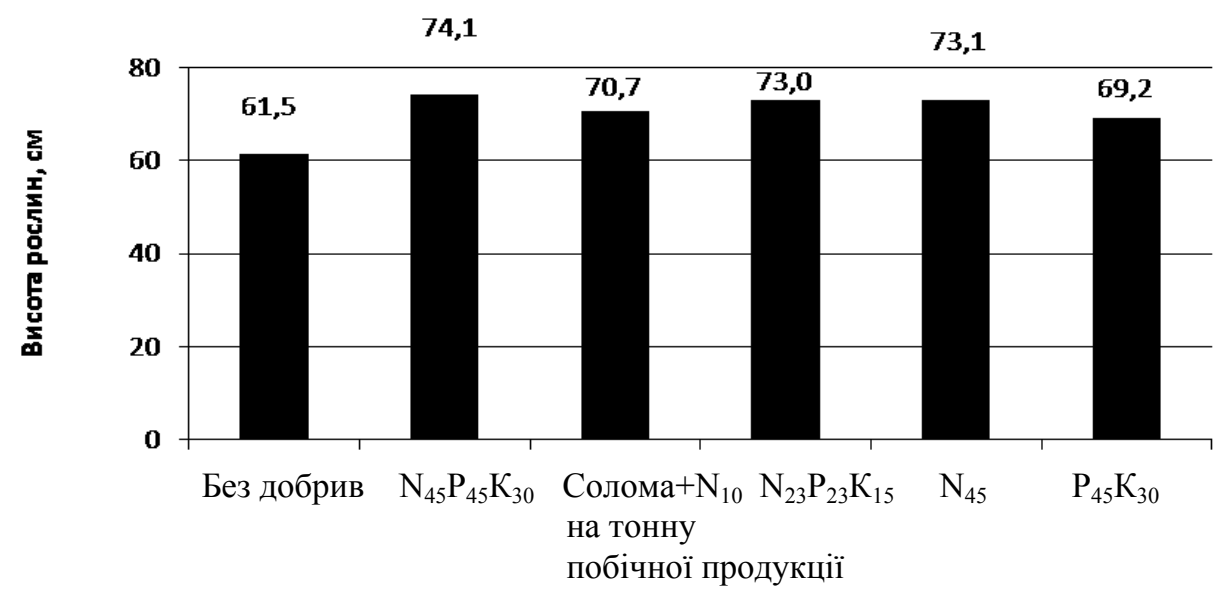

Рис. 3. Висота рослин пшениці твердої ярої залежно від впливу різних фонів удобрення (2010-2012 pp.)

Погодні умови 2011 року сприяли збільшенню висоти рослин пшениці до 84,0 см без застосування добрив. Обробка насіння біопрепаратами сприяла збільшенню висоти рослин до 86,7 см за обробки поліміксобактерином, до 85,5 cм - діазофітом, 86,4 см - суміші препаратів. На удобре- 
ному фоні $\mathrm{N}_{45} \mathrm{P}_{45} \mathrm{~K}_{30}$ висота рослин збільшилася до 90,2 см, за додаткової обробки діазофітом до 97,5 см; обробка насіння сумішшю препаратів сприяла збільшенню висоти рослин до 98,2 сантиметрів. На всіх інших удобрених фонах дія біопрепаратів на висоту рослин пшениці була дещо меншою (в межах 3-5\%).

У 2012 році посушливі умови вегетаційного періоду сприяли формуванню низькорослих рослин пшениці, висота яких становила 50,0-50,4 см на ділянках без застосування добрив, за їхнього внесення підвищувалася до 54,4-55,9 сантиметрів. Застосування біопрепаратів на різних фонах удобрення мало позитивну дію, що проявлялося в незначному прирості висоти рослин (1,0-3,0\%).

За результатами трьохрічних досліджень встановили позитивну дію біопрепаратів на висоту рослин пшениці, до того ж їхня дія коригувалася різними фонами мінерального живлення (рис. 1). Без застосування добрив висота рослин становила 63,6 см, застосовуючи поліміксобактерин підвищувалась - до 67,2, азотофіту - до 68,6 сантиметрів. Обробка насіння перед сівбою сумішшю двох препаратів не сприяла підвищенню висоти рослин (66,8 см) порівняно 3 їхнім окремим застосуванням. На всіх інших удобрених фонах біопрепарати сприяли підвищенню висоти рослин від 69,5 см без інокуляції до 71,3-77,7 см за іiі застосування $\left(\mathrm{N}_{45} \mathrm{P}_{45} \mathrm{~K}_{30}\right)$, а також, відповідно, на інших удобрених фонах: 68,2 i 71,0-72,0 (солома попередника + $\mathrm{N}_{10}$ на тону побічної продукції), 69,0 і 71,3-76,5 $\left(\mathrm{N}_{23} \mathrm{P}_{23} \mathrm{~K}_{15}\right), 66,4$ і $71,7-74,3\left(\mathrm{~N}_{45}\right), 65,4$ см і $70,1-$ $70,8 \mathrm{~cm}\left(\mathrm{P}_{45} \mathrm{~K}_{30}\right)$.

Вплив інокуляції зерна (рис. 2) та різних фонів мінерального живлення (рис. 3) свідчить, що ви-

\section{БІБЛІОГРАФІЯ}

1. Голик В. С. Яровая пшеница / В. С. Голик // Пшеница. - К. : Урожай, 1989. - С. 281-307.

2. Голик $B$. C. Создание сортов яровой мягкой и твердой пшеницы с высокими хлебопекарными и макаронными свойствами в Институте растениеводства им. В. Я. Юрьева / В. С. Голік // Наукові основи стабілізації виробництва продукції рослинництва. - Х., 2001. - С. 19-28.

3. Грииай А. Д., Камінський В. Ф., Романюк П. В. [ma iн.]. Чи $є$ альтернатива інтенсивним технологіям вирощування сільськогосподарських культур // Землеробство. - 1994. - Вип. 69. - С. 23.

4. Жемела Г. П. Поліпшення якості зерна польових культур за допомогою використання добрив/ Г. П. Жемела, Г. Г. Дуда // Удобрення польових культур при інтенсивних технологіях вирощування. - К. : Урожай, 1990. - С. 176-190. сота рослин, окремо в кожному досліді, за всіма варіантами була різною. Встановлено, що висота рослин пшениці твердої ярої за впливу поліміксобактерину збільшувалася на 3,4 см $(5,1 \%)$, діазофіту - на 6,0 см (9,0 \%), суміші поліміксобактерину та діазофіту - на 5,9 см (8,8 \%). Висота рослин на різних фонах мінерального живлення збільшувалася на 12,6 см $(20,5$ \%) за внесення $\mathrm{N}_{45} \mathrm{P}_{45} \mathrm{~K}_{30}$, на 9,2 см $(15,0 \%)$ - на ділянках удобрення (солома попередника $+\mathrm{N}_{10}$ на тонну побічної продукції), на 11,5 см (18,7 \%) - за удобрення $\mathrm{N}_{23} \mathrm{P}_{23} \mathrm{~K}_{15}$, на $11,6 \mathrm{~cm}(18,9 \%)$ - за удобрення $\mathrm{N}_{45}$, на 11,7 см $(19,0 \%)$ - за удобрення $\mathrm{N}_{45}$, на 7,7 см (12,5\%) - за удобрення $\mathrm{P}_{45} \mathrm{~K}_{30}$.

\section{Висновки:}

1. Застосування мінеральних добрив та інокуляції насіння пшениці ярої біопрепаратами позитивно вплинуло на ріст і розвиток рослин, що сприяло їх оптимальному розвитку незалежно від погодних умов.

2. Без застосування добрив висота рослин становила 63,6 см, за використання поліміксобактерину збільшувалася до 67,2, діазофіту - до 68,6 сантиметрів. Обробка насіння перед сівбою сумішшю двох препаратів не сприяла збільшенню висоти рослин $(66,8$ см) порівняно з їхнім окремим застосуванням.

3. Вплив мінеральних добрив на висоту рослин був суттєвішим, аніж дія біопрепаратів, але їхня комплексна дія мала більшу ефективність щодо збільшення ростових процесів у рослин пшениці твердої ярої; до того ж згладжувалася негативна дія несприятливих факторів вегетаційного періоду.

5. Мищустин Е. Н. Микроорганизмы и продуктивность земледелия / Е. Н. Мишустин. - М. : Наука, 1972. - 243 с.

6. Чуб М. П. Влияние удобрений на качество зерна яровой пшеницы / М. П. Чуб. - М. : Россельхозиздат, 1980. - 69 с.

7. Шевченко О. I. Продуктивність і якість зерна пшениці ярої за різних способів застосування фізіологічно активних речовин / О.І. Шевченко // Наукові праці Полтавської державної аграрної академії. - Полтава, 2005. - Т. 4 (23). - С. 280-285.

8. Шевніков Д. М. Вплив мінеральних добрив та мікробіологічних препаратів на формування врожайності пшениці твердої ярої / Д. М. Шевніков // Вісник Полтавської державної аграрної академії. - 2011. - № 4. - С. 165-168. 